\title{
PEN CULTURE SEBAGAI SOLUSI PENINGKATAN PENDAPATAN NELAYAN RAJUNGAN DI JEPARA
}

\section{PEN CULTURE AS A SOLUTION TO INCREASE BLUE SWIMMER CRAB FISHERMEN INCOME'S IN JEPARA}

\author{
${ }^{1)}$ Desti Setiyowati, ${ }^{2}$ Dwi Retna Sulistyowati \\ ${ }^{1)}$ Program Studi Budidaya Perairan, ${ }^{2}$ Program Studi Teknik Industri \\ Fakultas Sains Dan Teknologi \\ Universitas Islam Nahdlatul Ulama Jepara \\ Jl. Taman Siswa (Pekeng) Tahunan Jepara Jawa Tengah, Telp./Fax.: (0291) 595320 \\ email :desti.8@unisnu.ac.id dan retno.seis@unisnu.ac.id
}

\begin{abstract}
ABSTRAK
Kegiatan pengabdian dilaksanakan pada kelompok sasaran nelayan rajungan di Desa Demaan Jepara.Tujuan dari kegiatan pengabdian ini adalah untuk meningkatkan pendapatan nelayan rajungan dengan pemanfaatan teknologi teknik pen culture. Berdasarkan analisis situasi yang dilakukan maka dapat diidentifikasi permasalahan sebagai berikut: 1) Daerah penangkapan (fishing ground) yang terlalu jauh 2) Ketersediaan stok rajungan di pasar tidak terpenuhi akibat ketergantungan nelayan pada stok rajungan di laut 3) Harga yang tidak stabil. Berdasarkan permasalahan yang dihadapi mitra, maka solusi yang ditawarkan adalah penyuluhan, pembuatan teknik pen culture, pelatihan dan pendampingan.Saatini seluruh kegiatan telah selesai dilaksanakan dengan lancar dan hasil yang baik dengantingkat capaian program 100\%. Pendampingan dalam pemanfaatan teknik pen culture telah membantu nelayan rajungan dalam meningkatkan pendapatan. Sebelum adanya kegiatan ini atau masih mengandalkan penangkapan rajungan di laut rata-rata produksinya hanya $60 \mathrm{~kg}$ dengan omzet per bulan $\mathrm{Rp}$ 3.600.00,00. Setelah adanya kegiatan ini produksinya naik menjadi $70 \mathrm{~kg}$ dengan omzet per bulan $R p$ 4.200.00,00.
\end{abstract}

Kata kunci: Pen culture, Rajungan, Nelayan

\begin{abstract}
The purpose of this devotional activity is to increase the income of blue swimmer crab fishermen with the utilization of technological techniques of pen culture. Based on the analysis of the situation undertaken it can be identified problems as follows: 1) fishing ground area that is too far 2) Availability of crab stocks in the market is not met due to dependence of fishermen on the stock of crabs at sea 3) Unstable prices. Based on the problems faced by partners, the solutions offered are counseling, pen culture technique development, training and mentoring. Currently all activities have been completed smoothly and the results are good with $100 \%$ program achievement level. Assistance in the utilization of pen culture techniques has helped the blue swimmer crabfishermen to increase their income. Before the existence of this activity or still rely on catching crab in the sea average production of only $60 \mathrm{~kg}$ with sales turnover per month 3.600.000IDR. After this activity the production rose to 70 $\mathrm{kg}$ with turnover per month 4.200.000IDR.
\end{abstract}

Keyword: Pen culture, Blue swimmer crabs, Fishermen 


\section{PENDAHULUAN}

Rajungan (Portunus pelagicus) disebut juga blue swimmimg crab atau kepiting berenang merupakan salah satu jenis crustacea (berkulit keras) yang memiliki anatomi yang berbeda dengan ikan. Dagingnya terbungkus oleh suatu lapisan kulit daging yang terletak di bawah kulit keras(cangkang/karapas). Rajungan memiliki cangkang atau karapas yang melebar ke samping kaki bercapit yang panjang dan runcing (Romimohtarto \& Juwana, 2009)

Rajungan merupakan satu jenis dari kepiting suku Portunidae yang mempunyai anggota banyak jenis dan dapat dimakan.Nama rajungan umumnya dipakai untuk jenis Portunus pelagicus (LINANEUS).Jenis ini termasuk yang umum diperdagangkan.Ekspor kepiting Indonesia ditujukan ke berbagai Negara dalam berbagai bentuk olahan. Rajungan segar (hanya di es) di ekspor ke Singapura dan rajungan beku di ekspor ke Jepang.Kepiting dalam kaleng di ekspor ke Belanda.Basis pemasaran ekspor kepiting Indonesia cukup luas dan melebar mulai dari Asia sampai Eropa dengan berbagai jenis produk yang juga sangat bervariasi. Beberapa pengusaha pengalengan saat ini mulai mengembangkan komoditi ini untuk diekspor ke Eropa dan Amerika, bahkan "Philips Seafoods Indonesia Inc" berdomisili di Pemalang khususnya menangani pengalengan daging rajungan, $P$. pelagicus, untuk memenuhi permintaan Amerika (personal komunikasi) (Juwana, 1997).

Rajungan di Indonesia sampai sekarang masih merupakan komoditas perikanan yang memiliki nilai ekonomis tinggi.Sampai saat ini seluruh kebutuhan ekspor rajungan masih mengandalkandari hasil tangkapan di laut (Mania, 2007 dalam Ningrum, Ghofar \& Ain, 2017). Rajungan merupakan salah satu komoditas ekspor perikanan terbesar di Indonesia. Ekspor komoditas perikanan rajungan (Portunus pelagicus) Indonesia mencapai US\$ 414,4 per tahun atau sekitar Rp 5 triliun per tahun. Nilai ekspor rajungan 2005 yang masih berada di kisaran US\$130,9. Negara tujuan utama ekspor rajungan adalah Amerika Serikat (KKP, 2015).

Hingga saat ini ekspor rajungan ada diperingkat ketiga sampai keempat dari total nilai ekspor produk perikanan Indonesia setelah udang, tuna dan rumput laut. Pemenuhan bahan baku rajungan hingga saat ini masih tergantung pada hasil tangkapan di alam (BPBAP, 2013).

Salah satu desa di Jepara yang menjadi sentra penangkapan rajungan adalah Desa Demaan. Letak desa yang berada pada pesisir pantai memungkinkan bagi masyarakatnya menggantungkan hidup sebagai nelayan rajungan.Berdasarkan data statistik Desa Demaan nampak bahwa pekerjaan sebagai nelayan menjadi sumber penghasilan yang utama.

Sebagai wilayah yang memiliki pantai yang panjang, masyarakat nelayan di desa Demaan hingga saat ini belum mampu memenuhi kebutuhan stok rajungan yang memiliki nilai ekonomis tinggi.Harga satu kilogram rajungan dengan kualitas unggul memiliki karapas lebih dari $10 \mathrm{~cm}$ mencapai harga $\mathrm{Rp}$. 50.000,00 hingga Rp. 75.000,00.Harga tersebut sangat menguntungkan bagi nelayan, jika mampu memenuhi kebutuhan pasar $\pm 75.000 \mathrm{~kg}$ rajungan.Namun, kondisi saat ini nelayan masih bergantung penuh terhadap penangkapan rajungan di alam sehingga nelayan rajungan saat ini baru mampu memenuhi $\pm 25.000 \mathrm{~kg}$ rajungan.

Dampak dari kondisi tersebut akhirnya kebutuhan rajungan dipenuhi oleh konsumendengan mengambil dari daerah lain. Hal ini menyebabkan aktivitas nelayan rajungan seringkali tidak mampu 
menjadi sumber ekonomi bagi masyarakat, karena ketergantungan pada musim atau alam masih sangat tinggi.Walaupun rajungan memiliki nilai jual tinggi, akan tetapi tidak mampu mengangkat ekonomi masyarakat. Selain itu, permasalahan lain yang selalu dikeluhkan adalah semakin jauhnya daerah penangkapan (fishing ground) rajunganmengakibatkan tingginya biaya operasional yang dikeluarkan tidak sebanding dengan penghasilan yang diperoleh nelayan.

Oleh karena itu, di rasakan perlunya penerapkan teknik yang dapat menjadi solusi bagi nelayan rajungan dalam memenuhi kebutuhan pasar, yang tidak lagi bergantung pada stok rajungan di alam, musim penangkapan, maupun jarak fishing ground yang semakin jauh.Tujuan dari kegiatan pengabdian ini adalah untuk meningkatkan pendapatan nelayan rajungan dengan pemanfaatan teknologi teknik pen culture.

\section{METODE}

Kelompok sasaran pengabdian pada masyarakat adalah Kelompok Nelayan Rajungan di Desa Demaan.Nelayan tersebut merupakan nelayan yang menggantungkan hidup sepenuhnya dari penangkapan rajungan dengan menggunakan alat tangkap bubu. Saat tidak sedang musim rajungan nelayan ini akan beralih profesi mencari pekerjaan lain seperti menangkap ikan, buruh bangunan dan lain-lainnya.

Berdasarkan gambaran dari potret permasalahan yang dihadapi mitra, tolok ukur transfer teknologi ini adalah dengan menyasar 10 orang nelayan sebagai perwakilan kegiatan untuk dilatih dalam hal budidaya rajungan.Teknologi yang digunakan adalah pemberdayaan mitra terhadap teknik pen culture dalam mempertahankan kontuinitas rajungan.

Pelaksanaan kegiatan ini dilakukan dengan memberikan sosialisasi pada satu desa secara keseluruhan, meskipun secara teknis kegiatan ini di fokuskan pada dua kelompok sasaran yang menjadi prioritas utama.Diharapkan anggota kelompok yang terlibat adalah anggota yang mampu menjadi pioneer untuk mentransferkan dan menjadi contoh bagi masyarakat sekitar khususnya nelayan rajungan.

Transfer teknologi pada mitra nelayan rajungan adalahteknik budidaya rajungan pen culturedengan memanfaatkan perairan lautdangkal, yang diharapkan mampu memenuhi kebutuhan pasar rajungan, yang sampai saat ini belum mampu dipenuhi.

\section{HASIL DAN PEMBAHASAN}

Kegiatan pengabdian kepada masyarakat berupa transfer teknologi tentang budidaya rajungan sistem pen cultureadalah sebagai upaya dalam meningkatkan pendapatan nelayan rajungan di Desa Demaan Jepara.Menurut (Effendi, 2004), pen cultureadalah sistem budidaya berupa kandang dengan dinding terbuat dari jaring yang ditunjang oleh patok kayu, sementara dasar kandang berupa dasar perairan (dinding alam). Adapun Proses Budidaya Rajungan Sistem Pen Culture adalah sebagai berikut :

1. Tahap 1 adalah pemilihan lokasi budidaya. Tahap ini merupakan langkah awal dalam menentukan keberhasilan usaha budidaya rajungan. Pemilihan lokasi rajungan sedapat mungkin harus disesuaikan dengan kebiasaan hidup atau habitat asli dari jenis rajungan yang akan dibudidayakan. Pada tahap ini, yang perlu di perhatikan adalah kedalaman air, sumber air, bentuk dasar perairan, perlindungan dari hantaman arus dan juga segi keamanannya.

2. Tahap 2 adalah pembuatan dan pemasangan pen culture. Pembuatan pen culture terdiri dari patok kayu dan jaring yang memiliki mesh size di atas $25 \mathrm{~mm}$. Pemasangan pen culture ditempatkan di perairan laut dangkal yang terlindung (protected shallow 
Desti Setiyowati dan Dwi Retna Sulistyowati Pen Culture Sebagai Solusi Peningkatan Pendapatan Nelayan Rajungan di Jepara

sea), terutama di kawasan dangkal (1-3 $m$ pada saat pasang) dan rata ( $m u d$ flat/reef flat) dengan kisaran pasang surut tidak terlalu lebar (1-2 m). Patok kayu ditancapkan dengan ketinggian sedikit lebih tinggi dari pasang tertinggi (HHWL, high high water level) sehingga pada saat pasang pen culture tidak tenggelam. Pada patok tersebut dipasangi jaring setinggi patok dan bagian bawah jaring dibenamkan ke dasar laut sedalam $0,5-1,0 \mathrm{~m}$ untuk menghindari rajungan menerobos ke luar kandang dengan cara menggali dasar laut, sehingga diperlukan luasan $5000 \mathrm{~m}^{2}$.

3. Tahap 3 adalah penebaran benih. Benih rajungan didapatkan dari panti pembenihan (hatchery) BBPAP Jepara sebab benih rajungan tersebut sudah diseleksi sehingga didapatkan benih rajungan yang unggul. Benih rajungan yang unggul menentukan keberhasilan dalam usaha budidaya rajungan. Kepadatan penebaran benih yaitu 10-30 ekor/ $\mathrm{m}^{2}$. Ukuran pen culture dengan luas 50 x 100 meter dapat diisi bibit rajungan sebanyak 10.000 ekor. Gunanya untuk menghindari rajungan saling memakan (kanibal) atau tempat yang terlalu sempit bagi rajungan bergerak aktif.

4. Tahap 4 adalah pemberian pakan. Budidaya dengan menggunakan sistem pen culture, terutama dengan luasan lebih dari 1 ha dan dengan kepadatan rendah $\left(0,1 \quad \mathrm{ekor} / \mathrm{m}^{2}\right)$, tidak perlu dilakukan pemberian pakan (no feeding). Pakan mengandalkan keberadaan pakan alami yang terdapat dalam sistem tersebut. Namun demikian, untuk memacu pertumbuhan rajungan perlu diberi pakan dari luar yaitu berupa ikan rucah (ikan- ikan kecil yang sudah diproses pengeringan). Pemberian pakan pada rajungan sebenarnya tidak ditebarkan setiap hari, bisa dilakukan 5 hari hingga seminggu sekali. Tetapi untuk mengurangi resiko rajungan saling memakan satu dengan yang lainnya, maka bisa dilakukan lebih sering.

5. Tahap 5 adalah pengontrolan. Pada periode tertentu disarankan dilakukan kontrol populasi. Untuk itu, pen segera ditelusuri, barangkali ada bagian yang rusak atau kurang rapat. Berkurangnya populasi rajungan juga bisa disebabkan oleh hama yang menyusup masuk ke sistem pen.

6. Tahap 6 adalah pemanenan. Rajungan dapat dipanen dengan dua metode: (1) pemanenan sedikit/pemilihan, metode ini digunakan apabila rajungan tersebut tidak mengalami perkembangan yang normal atau sudah memasuki musim panen tetapi masih banyak rajungan yang ukurannya di bawah standart jual beratnya telah melebihi 100 gram (2) pemanenan masal, dilaksanakan ketika rajungan seluruhnya dipandang layak dijual di pasaran. Setelah dipanen sebaiknya rajungan dibawa langsung ke pasar.

Kegiatan pengabdian kepada masyarakat ini telah selesai dilaksanakan. Kegiatan tersebut dimulai dari sosialisasi dan pelatihan pembuatan pen culture, budidaya rajungan (pembesaran), analisis usaha budidaya rajungan. Hal yang masih berlangsung sampai saat ini adalah pendampingan kelompok dalam hal manajemen produksi rajungan.

Berdasarkan permasalahan yang dihadapi oleh mitra dalam kaitannya dengan upaya menjaga kontuinitas rajungan di pasaran serta pengembangan wawasan pengetahuan dan keterampilan budidaya rajungan, maka program pengabdian masyarakat ini dilakukan dalam bentuk transfer iptek yang dilakukan berupa sosialisasi, pelatihan, dan pendampingan kepada nelayan rajungan di desa Demaan. Sebelum adanya program ini atau masih mengandalkan penangkapan rajungan di laut. Menurut (Santoso; Karman; Japa \& Raksun, 2016), rajungan hasil tangkapan para nelayan dijual pada para pengumpul (bakul). Para pengumpul 
Desti Setiyowati dan Dwi Retna Sulistyowati Pen Culture Sebagai Solusi Peningkatan Pendapatan Nelayan Rajungan di Jepara

ini menjual rajungannya kepada parabandarbesar yang merupakan agen pembelian dari perusahaan-perusahaan besar (eksportir) rajungan. Hasil tangkapan nelayan rajungan rata-rata produksinya hanya $60 \mathrm{~kg}$ dengan omzet per bulan Rp 3.600.00,00. Setelah adanya kegiatan pengabdian ini produksinya naik menjadi $70 \mathrm{~kg}$ dengan omzet per bulan $\mathrm{Rp}$ 4.200.00,00.

Sosialisasi dan pelatihan analisis usaha budidaya rajungan yangtim pelaksana selenggarakan bertujuan untuk menunjang tingkat pengetahuan dan wawasan nelayan rajungan agar bias memiliki bekal manajemen usaha berupa pembukuan sederhana berupa arus pengeluaran dan pemasukan.

Dalam mengukur tingkat keberhasilan kegiatan yang telah dilakukan, maka dilakukan evaluasi minimal 3 (tiga) kali, yaitu evaluasi proses,evaluasi akhir,dan evaluasi tindak lanjut.Kegiatan evaluasi ini melibatkan tutor atau pakar dari UNISNU Jepara. Kriteria dan indicator pencapaian tujuan dan tolak ukur yang digunakan untuk menjastifikasi tingkat keberhasilan kegiatan. Hal ini dapat dilihat dari hasil diskusi dan evaluasi yang dilakukan oleh tim pelaksana,terhadap pengetahuan dan keterampilan peserta sosialisasi dan pelatihan.Berdasarkan evaluasi tindak lanjut yang dilakukan, didapatkan bahwa nelayan rajungan di Desa Demaan yang mengikuti pelaksanaan program memiliki pengetahuan yang konsisten mengenai keterampilan pembuatan pen culture dan budidaya (pembesaran) rajungan. Dengan demikian, sesuai dengan criteria keberhasilan program, maka sosialisasi dan pelatihan inidinilai berhasil apabila mampu meningkatkan pengetahuan dan wawasan peserta pelatihan.

Berdasarkan hasil evaluasi tidak lanjut,ada beberapa manfaat praktis yang diperoleh oleh nelayan rajungan di Desa Demaan yaitu:
1. Peserta pelatihan mendapatkan informasi yang jelas dan utuh mengenai hakekat pemberdayaan masyarakat dari segi pengetahuan dan keterampilan, bermakna untuk meningkatkan pendapatan yang sifatnya inovatif dari pengembangan teknik budidaya rajungan.

2. Peserta pelatihan mendapatkan gambaran yang jelas dan utuh tentang manfaat hasil budidaya rajungan dengan teknik pen culture apabila dikelola dengan baik.

Kendala pelaksanaan program adalah sulitnya mengatur waktu untuk pencapaian kesepakatan bersama dalam hal pelaksanaan kegiatan, karena umumnya peserta pelatihan terbentur dengan rutinitas pekerjaan harian yang menunjang perekonomian keluarga yaitu miang atau menangkap rajungan di laut. Oleh sebab itu, untuk bisa mengkoordinir para peserta pelatihan perlu komunikasi yang intensif sehingga diperoleh kesepakatan bersama.

Tindak lanjut yang harus dilakukan adalah tetap melakukan koordinasi dan pemantauan mengenai perkembangan hasil pelatihan yang telah dikembangkan peserta, dan sewaktu-waktu tim pelaksana akan melakukan peninjauan ke lapangan untuk mengukur tingkat ketercapaian program yang telah terlaksana. Koordinasinya tetap melibatkan kerja sama antara LPPM,tim pelaksana pengabdian masyarakat dan dinas terkait.

\section{SIMPULAN}

Tingkat partisipasi yang tinggi dari mitra program pengabdian kepada masyarakat memberikan dampak positif bagi pelaksanaan program,terlihat dari pelatihan dan pendampingan pembuatan pen culture, budidaya (pembesaran) rajungan dan analisis usaha budidaya rajungandapat berjalan dengan baik Pelaksanaan program mampu menghasilkan luaran-luaran yang diharapkan oleh program pengabdian kepada masyarakat ini, antara lain 
Desti Setiyowati dan Dwi Retna Sulistyowati Pen Culture Sebagai Solusi Peningkatan Pendapatan Nelayan Rajungan di Jepara

peningkatan pengetahuan dan keterampilan teknik budidaya rajungan menggunakan pen culture dan peningkatan pendapatan nelayan rajungan.

\section{DAFTAR PUSTAKA}

BPBAP. (2013). Teknologi Pembenihan Rajungan (Portunus pelagicus, Linnaeus 1758). Takalar: KKP, Direktorat Jenderal Perikanan Budidaya .

Effendi, I. (2004). Pengantar Akuakultur. Jakarta: Penebar Swadaya.

Juwana, S. (1997). Tinjauan tentang Perkembangan Penelitian Budidaya Rajungan (Portunus pelagicus). Oseana, XXII, (4), 1 $-12$.
KKP. (2015). Ekspor Rajungan Indonesia Sumbang Rp 5 Triliun. Retrieved Maret 5, 2015, from http://agro.kemenperin.go.id/.

Ningrum, V. P., Ghofar, A., \& Ain, C. (2015). Beberapa Aspek Biologi Perikanan Rajungan (Portunus pelagicus) Di Perairan Betahwalang dan Sekitarnya. Saintek Perikanan, 11(1), 62-71.

Romimohtarto, K., \& Juwana, S. (2009). Biologi Laut : Ilmu Pengetahuan tentang Biota Laut. Jakarta: Djambatan.

Santoso, D., Karman; L. Japa \& Raksun. (2016). Karakteristik Bioekologi Rajungan (Portunus Pelagicus) Di Perairan Dusun Ujung Lombok Timur. Biologi Tropis, 16(2), 94-105. 